\title{
KARAKTERISTIK DNA CO1 SERANGGA LAUT Gerridae YANG BERASAL DARI PANTAI MOKUPA SULAWESI UTARA
}

\section{(Characteristics of marine insects Gerridae CO1 DNA from Mokupa Beach North Celebes)}

\author{
R.T.D. Maramis ${ }^{1}$, V. Warouw ${ }^{2 \star}$
}

1. Fakultas Pertanian, Universitas Sam Ratulangi Manado.

2. Program Studi Ilmu Kelautan, Fakultas Perikanan dan Ilmu Kelautan, Universitas Sam Ratulangi Manado.

*e-mail : veibe.warouw@yahoo.co.id

Characterization of mitochondrial DNA gene cytochrome oxidase subunit 1 (CO1) of marine insects Gerridae from Mokupa, North Sulawesi, after further extracted DNA was amplified by PCR, electrophoresis and sequenced, then the results of CO1 sequences is entered to BLAST program to get the level of homology with sequences from the $\mathrm{NCBI}$ gene bank, the results only turned out to have the highest degree of homology of $\leq 87 \%$ with sequences obtained. The results showed that the gene sequences of cytochrome oxidase 1 (CO1) of insects Gerridae sea from Mokupa, North Sulawesi is not the same as other Gerridae marine insects have been recorded and published in the NCBI gene bank.

Keywords : Marine Insect, Gerridae,CO1

Karakterisasi DNA mitokondria yaitu gen sitokrom oksidase sub unit 1 (CO1) dari serangga laut Gerridae yang berasal dari pantai Mokupa, Sulawai Utara, setelah diekstraksi DNA yang selanjutnya diamplifikasi dengan metode PCR, elektroforesis dan disekuensing, hasil Sekuen CO1 kemudian di BLAST untuk mendapatkan tingkat homology dengan sekuenssekuens dari gene bank NCBI, ternyata hanya memiliki tingkat homologi paling tinggi sebesar $\leq 87 \%$ dengan sekuens yang diperoleh. Hasil penelitian menunjukkan bahwa sekuens gen sitokrom oksidase 1 (CO1) dari serangga laut Gerridae yang berasal dari pantai Mokupa, Sulawesi Utara tidak sama dengan serangga laut Gerridae lain yang telah terdata dan terpublikasi di gen bank NCBI .

Kata kunci : Serangga laut, Gerridae, CO1

\section{PENDAHULUAN}

Serangga tidak diragukan lagi adalah hewan yang paling umum di darat, tetapi sangat sedikit didapati yang hidup di laut. Sebagai spesies terbanyak dari semua spesies hewan, hanya sekitar $3 \%$ yang merupakan serangga air atau memiliki tahap hidup di berbagai habitat perairan dan hanya sedikit yang ditemukan di perairan laut serta pesisir pantai. Namun, hewan ini sebenarnya cukup banyak terwakili dalam beragam habitat pesisir pantai atau laut. Dari jumlah tersebut mungkin hanya beberapa ratus spesies, yang hidup di laut atau daerah pasang surut. Sebagian besar serangga laut ditemukan di zona pasang surut, yang dapat dikategorikan lebih lanjut oleh jenis vegetasi yang terkait dengan mereka, misalnya lamun (Spartina dan Juncus), rumput laut (hijau, biru-hijau, coklat, atau merah), bakau (Rhizophora, Avicennia, Bruguiera, dan Sonneratia), atau tumbuhan tingkat tinggi lainnya (Xylocarpa dan Acanthus) (Cheng, 1966, 1976, 1985, 1989).

Heteroptera merupakan bagian terbesar dari serangga kelas Hemiptera, dengan jumlah lebih dari 42.000 spesies yang teridentifikasi dari 140 
famili. Ordo ini memiliki peranan penting baik sebagai hama, vektor penyakit dan sebagai kontrol biologi. Serangga yang hidup di permukaan laut adalah anggota dari family Gerridae, dapat ditemukan di berbagai habitat mulai dari dekat pantai, sungai, bakau, terumbu, intertidal, laguna pesisir, dan muara, hingga laut terbuka. Sebagian besar spesies ditemukan di wilayah Indo-Pasifik. Serangga ini merupakan organisme yang kecil, hanya berukuran sekitar 0,5-1 cm panjang badan, tetapi memiliki kaki agak panjang dan mungkin memiliki rentang kaki $1,5 \mathrm{~cm}$ atau lebih, tidak bersayap pada semua tahap siklus hidup mereka dan berada di atas permukaan laut-udara. Lebih dikenal dengan sebutan sea skater atau ocean strider karena kemampuanya untuk berjalan di permukaan air (Cheng 1975 dalam Andersen \& Cheng 2004). Genus terbaik dipelajari dari segi taksonomi, distribusi, ekologi, phylogeny, dan evolusi adalah Halobates. Genus ini hampir secara eksklusif hidup di laut dan terdiri dari 45 spesies, termasuk 5 spesies yang hidup sepenuhnya pelagis di permukaan laut.

Salah satu metode yang dapat digunakan untuk menelusuri hubungan filogenetik suatu spesies yang telah diterima keakuratannya secara universal adalah melihat kemiripan DNA mitokondria (mtDNA). Banyak penelitian untuk studi filogeni hewan baik invertebrata maupun vertebrata menggunakan gen CO I mtDNA sebagai marker/barcode genetik. Gen COI merupakan salah satu gen yang dapat digunakan sebagai penanda genetik, dalam studi molekuler untuk mempelajari karakteristik genetik antar spesies maupun antar individu (Folmer et al. 1994).

Laut Sulawesi Utara menyimpan banyak kekayaan akan keanekaragaman biota laut yang belum tergali, salah satunya adalah data tentang keberadaan serangga- serangga yang hidup di perairan laut Sulawesi Utara terutama dari Family Gerridae. Sehingga perlu diadakan studi molekular untuk mendapatkan keragaman genetik gen CO1 mtDNA dari serangga yang hidup di perairan Sulawesi Utara dan membandingkan dengan sekuens gen $\mathrm{CO} 1$ yang telah terdata di gene bank NCBI. Sampai saat ini, belum ada data karakteristik gen CO1 serangga yang berasal dari Sulawesi Utara sehingga hasil penelitian ini akan memberikan informasi penting tentang karakter genetik serangga yang mendiami daerah pantai Sulawesi Utara khususnya dari famili Gerridae.

\section{METODE PENELITIAN}

\section{Pengambilan sampel}

Sampel diambil dari perairan Pantai Mokupa pada bulan Mei 2013, khususnya pada daerah mangrove. Pengambilan sampel serangga dilakukan dengan bantuan neuston net. Serangga yang telah dikoleksi dimasukkan ke dalam botol sampel berisi alkohol $95 \%$ yang telah diberi label data tempat dan waktu pengambilan sampel.

\section{Identifikasi DNA}

Untuk identifikasi DNA sampel, gen akan di ekstrak dan di isolasi dengan menggunakan AxyPrep multisource genomic DNA miniprep Kit, Axygen Biosciences, dan dengan primer CO1, LCO1490 : 5'GTCAACAAATCATAAAG ATATTGG-3' dan HCO2198:5'-

TAAACTTCAGGGTGACCAAAAAATC A-3' (Folmer et.al.,1994), gen akan diamplifikasi menggunakan PCR.

\section{Ekstraksi dan Isolasi DNA}

Serangga yang dikumpulkan, disimpan beku di freezer. Ekstraksi diawali dengan merendam serangga dalam ependorf yang kemudian ditambahkan dengan $\mathrm{DH}_{2} \mathrm{O}$ sebanyak 
$350 \mu \mathrm{l}$ lalu dihancurkan dengan pestel, sheker selama $1 \mathrm{mnt}$. Pada tahap isolasi menggunakan prosedure isolasi jaringan dari Axygen Bioscience yang diawali dengan ditambahkan $350 \mu \mathrm{l}$ PBS untuk mencuci pada ependorf berisi serangga, kemudian ke dalam ependorf tersebut ditambahkan 0,9 $\mu \mathrm{l}$ RNAase untuk mencuci RNA kemudian dihomogenkan dengan menggunakan vortex selama 30 dtk. Untuk menghancurkan protein ditambahkan $20 \mu$ l Proteinase $\mathrm{K}$ dan 150 Buffer $\mathrm{Cl}$ dan kembali di homogenkan menggunakan vortex selama $1 \mathrm{mnt}$. Inkubasi dilakukan selama 3 jam pada suhu $56^{\circ} \mathrm{C}$ dengan menggunakan heater. Setelah diinkubasi,ditambahkan sebanyak $350 \mu \mathrm{l}$ buffer P-D dan di homogenkan menggunakan vortex selama 30 detik. Untuk mendapatkan supernatant,di lakukan sentrifugasi pada $12.000 \times \mathrm{g}$ selama 10 mnt. Supernatant yang diperoleh dimasukkan dalam miniprep column yang sudah berada dalam tube microfuge $2 \mathrm{ml}$, kemudian disentrifus selama satu mnt pada $12.000 \times \mathrm{g}$. Filtrat yang didapat dibuang dan miniprep hasil sentrifuse diletakkan kembali pada microfuge tube $2 \mathrm{ml}$ yang baru. Kedalamnya ditambahkan $700 \mu \mathrm{l}$ buffer $W_{1}$, kemudian disentrifuse selama $1 \mathrm{mnt}$ pada $12.000 \times \mathrm{g}$, filtrate dibuang dan ditambahkan dengan 700 $\mu$ buffer $W_{2}$ dan kembali disentrifuse selama $1 \mathrm{mnt}$ pada $12.000 \mathrm{x} \mathrm{g}$. Presipitat dipindahkan pada mini colom pada 1,5 microfuge tube, lalu tambahkan $100 \mu \mathrm{l}$ eluent kemudian diusentrifuse selama $1 \mathrm{mnt}$ pada 12.000x $g$ setelah sebelumnya didiamkan pada suhu ruang selama 2 mnt. Filtrat DNA yang didapatkan disimpan dalam suhu $-20^{\circ}$.

\section{Amplifikasi PCR}

Untuk proses amplifikasi DNA dengan CO1 menggunakan PCR, supernatant yang didapat dimasukkan sebanyak $10 \mu \mathrm{l}$ dalam ependorf $1 \mathrm{ml}$ kemudian ditambahkan $2 \mu \mathrm{l}$ primer reverse, $2 \mu \mathrm{l}$ primer foreward, $1 \mu \mathrm{l}$ $\mathrm{MgCl}_{2}, 25 \mu \mathrm{l}$ taqpol $2 \times$ mastermix, $2 \mu \mathrm{l}$ DNA template dan $19 \mu \mathrm{l} \mathrm{DH}_{2} \mathrm{O}$. Proses amplifikasi dalam PCR dilakukan pada kondisi redenaturasi $95^{\circ} \mathrm{C}$ selama $2 \mathrm{mnt}$, denaturasi $95^{\circ} \mathrm{C}$ selama $40 \mathrm{dtk}$, annealing $50^{\circ} \mathrm{C}$ selama $40 \mathrm{dtk}$, extension $72{ }^{\circ} \mathrm{C}$ selama $50 \mathrm{dtk}$, final extention $72{ }^{\circ} \mathrm{C}$ selama $1 \mathrm{mnt}$, dengan pengulangan sebanyak 35 siklus.

Kemudian dengan menggunakan elektroforesis didapatkan fragmen hasil amplifiksi dengan PCR, band yang paling bagus yang terlihat dikumpulkan dan di kirim ke First Base CO. Malaysia untuk disekuensing. Hasil sekuensing berupa urut-urutan DNA dibaca dengan metode BLAST dan dibandingkan dengan bank gen, sehingga didapatkan genus dari serangga yang dijadikan sampel.

\section{HASIL DAN PEMBAHASAN}

Serangga laut yang ditemukan pada daerah pesisir pantai Mokupa didapati mempunyai populasi yang tinggi pada daerah mangrove yang tenang dan sangat sedikit pada daerah berpasir dan berombak. Berada dipermukaan air laut dan bergerak dengan cara melompat dengan mempergunakan kekuatan tegangan permukaan air laut. Menurut Cheng (1976) serangga ini mempunyai semacam lapisan lilin pada telapak kaki, sehingga mempermudah untuk berjalan di atas air dengan tungkai yang panjang serta tubuh yang kecil (Gambar 1), memungkinkan serangga ini tidak tenggelam ketika berjalan di atas air. Bagian permukaan tubuh serangga ini ditutupi oleh rambut hydrofuge yang diketahui berguna untuk memerangkap udara, sehingga mencegah mereka basah dan tenggelam ketika terbawa ombak kedasar air. Adaptasi pernapasan lain khusus pada sistem trakea meliputi bernapas dengan menggunakan 


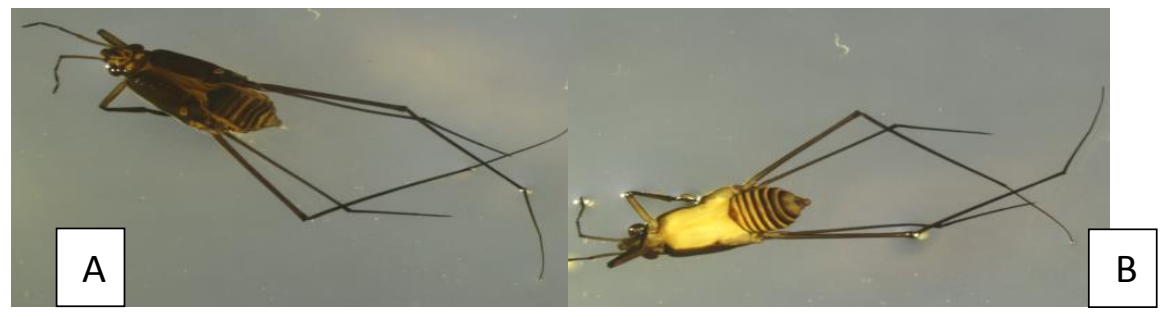

Gambar 1. Serangga laut yang ditemukan pada daerah pesisir pantai Mokupa

A. Dorsal

B. Ventral

Gambar 2. Visualisasi DNA mitokondria dari serangga laut yang diamplifikasi dengan primer $\mathrm{CO} 1$

sifon-blood gills dan berbagai jenis 'insang fisik' (Andersen, N.M. 1998, 2004; Andersen, N.M., and T.A. Weir. 1994).

\section{Ekstraksi DNA}

Hasil ekstraksi DNA dari satu individu serangga yang sudah diawetkan dalam $95 \%$ alkohol yang diisolasi dengan menggunakan AxyPrep multisource genomic DNA miniprep Kit, Axygen Biosciences, dan dengan menggunakan primer CO1, LCO1490: 5'GGTCAACA AATCATAAAGATATTGG3' dan CO2198: 5'-
TAAACTTCAGGGTGACCAAAAAATC A-3', kemudian diamplifikasi menggunakan PCR, hasil amplifikasi dengan PCR kemudian divisualisasi dengan menggunakan elektroforesis dengan hasil seperti yang terlihat pada Gambar 2.

\section{Analisis Sekuens CO1 dengan Program BLAST}

Sekuensing DNA serangga laut dari First Base CO. Malaysia ternyata mempunyai panjang sebanyak 658 sekuen fragmen dna dengan urutan seperti tertera pada Gambar 3. 


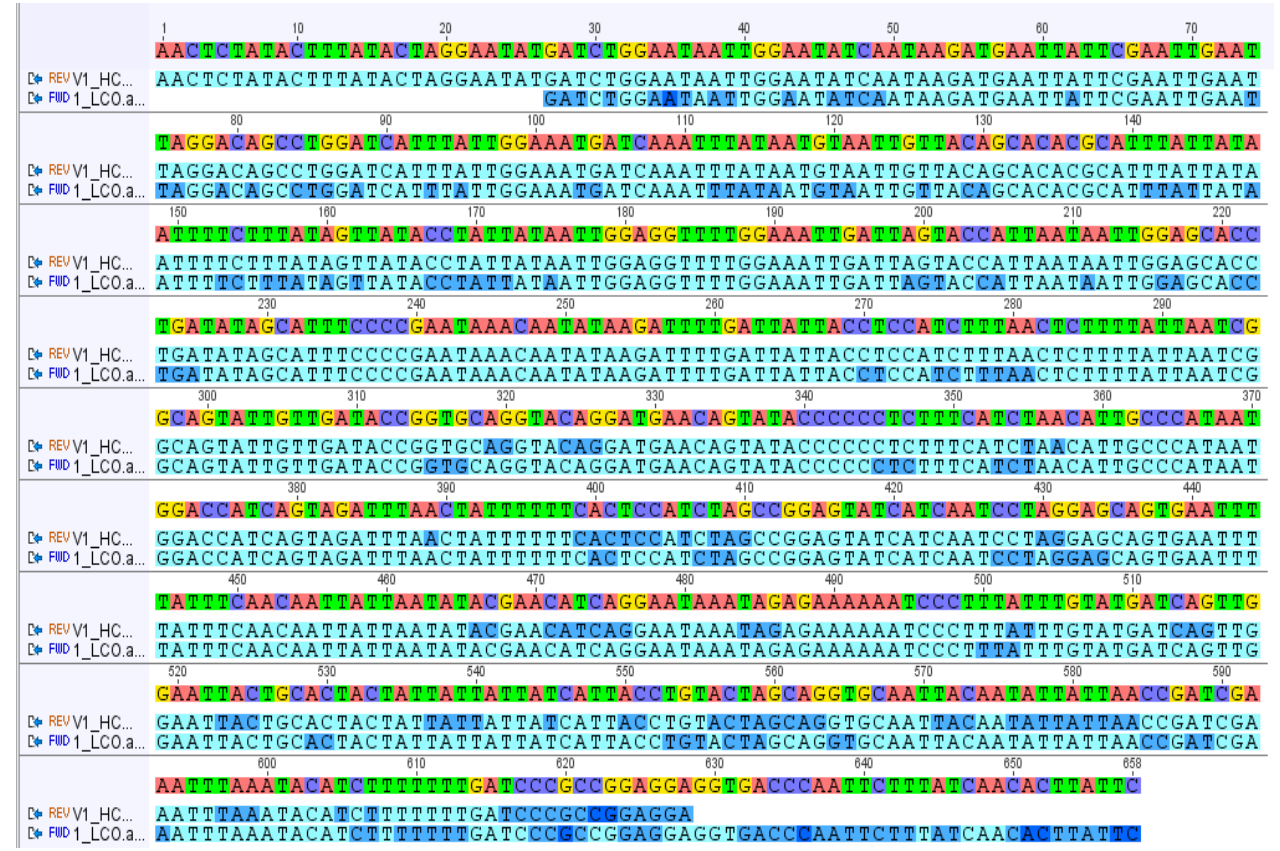

Gambar 3. Konsensus urutan sekuen fragmen DNA serangga laut dengan menggunakan primer $\mathrm{CO} 1$

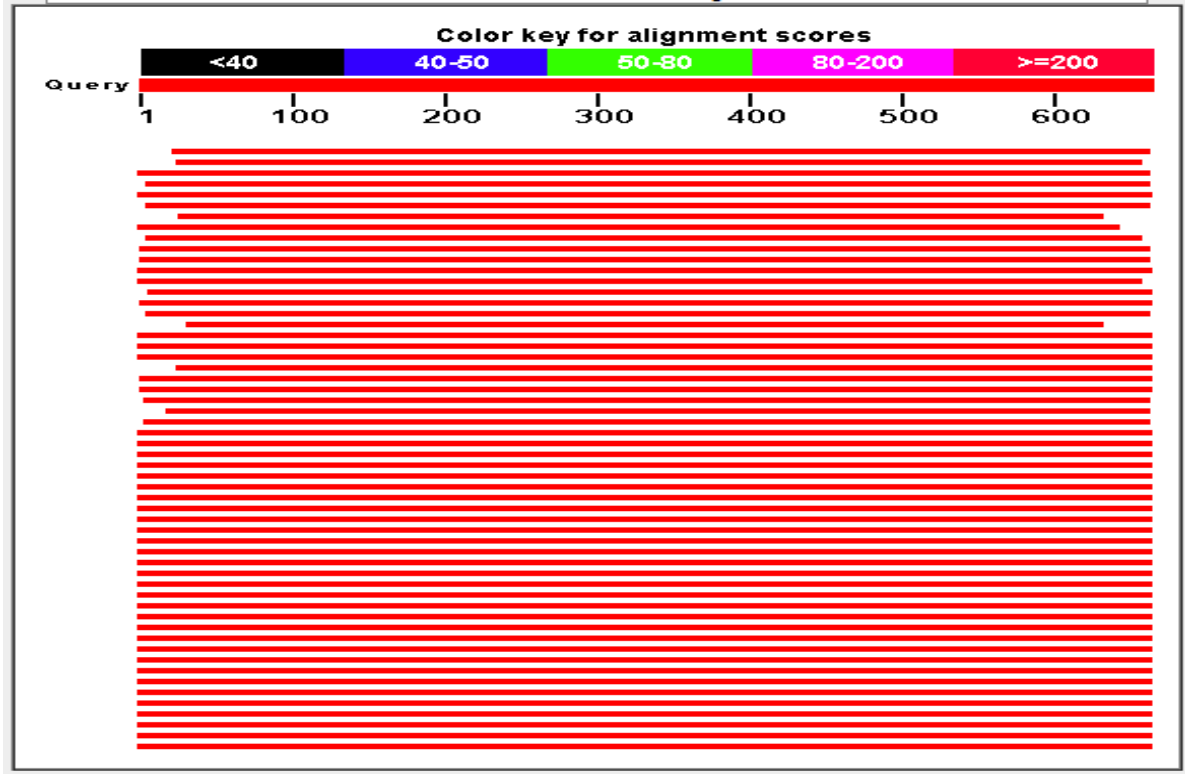

Gambar 4. Tingkat kesamaan sekuen gen CO1 (658 bp) dari serangga laut dengan data di gene bank NCBI (www.ncbi.nlm.nih.gov). 
Hasil sekuen fragmen DNA gen sitokrom oksidase 1 (CO1) dari serangga laut yang diperoleh dianalisis dengan data sejenis yang telah lebih dahulu dipublikasikan di gene bank. Analisis yang dilakukan adalah analisis penyejajaran yaitu membandingkan sekuen gen CO1 serangga luat yang diperoleh dengan sekuen gen $\mathrm{CO} 1$ dari organisme lain yang telah terdata di gene bank. Program yang digunakan untuk analisis penyejajaran adalah program BLAST (Basic Local Allignment Search Tools). Program ini dapat diakses melalu website National Center for Biotechnology Information at The National Library of Medicine in Washington,DC (http://www.ncbi.nlm.nih. gov/BLAST). Hasil BLAST diperoleh 58 data dari gene bank yang memiliki tingkat indetik/homologi $>\quad 83 \%$, seperti digambarkan pada Gambar 4.
Untuk analisis lanjut hanya difokuskan pada organisme dengan tingkat homologi/indetik $\geq 85 \%$. Hasil analisis dengan tingkat identik tertinggi sebesar $87 \%$ pada beberapa serangga laut dari famili Gerridae yang terdata pada gene bank NCBI adalah Rhagovelia tenuipes (JN 689491.1) dan Microvelia longipes (JN 689488.1), sedangkan Gerris Marginatus (AY252904.1) dan Aquarius remigoides (HQ105440.1) hanya mempunyai tingkat identik sebanyak $86 \%$ dan Aquarius paludum (GQ292292.1) mempunyai tingkat identik sebanyak $85 \%$ Adapun kekerabatan dari serangga laut yang ditemukan pada dareah perairan Pantai Mokupa dengan beberapa serangga berdasarkan data di gene bank NCBI tergambar pada Gambar 5.

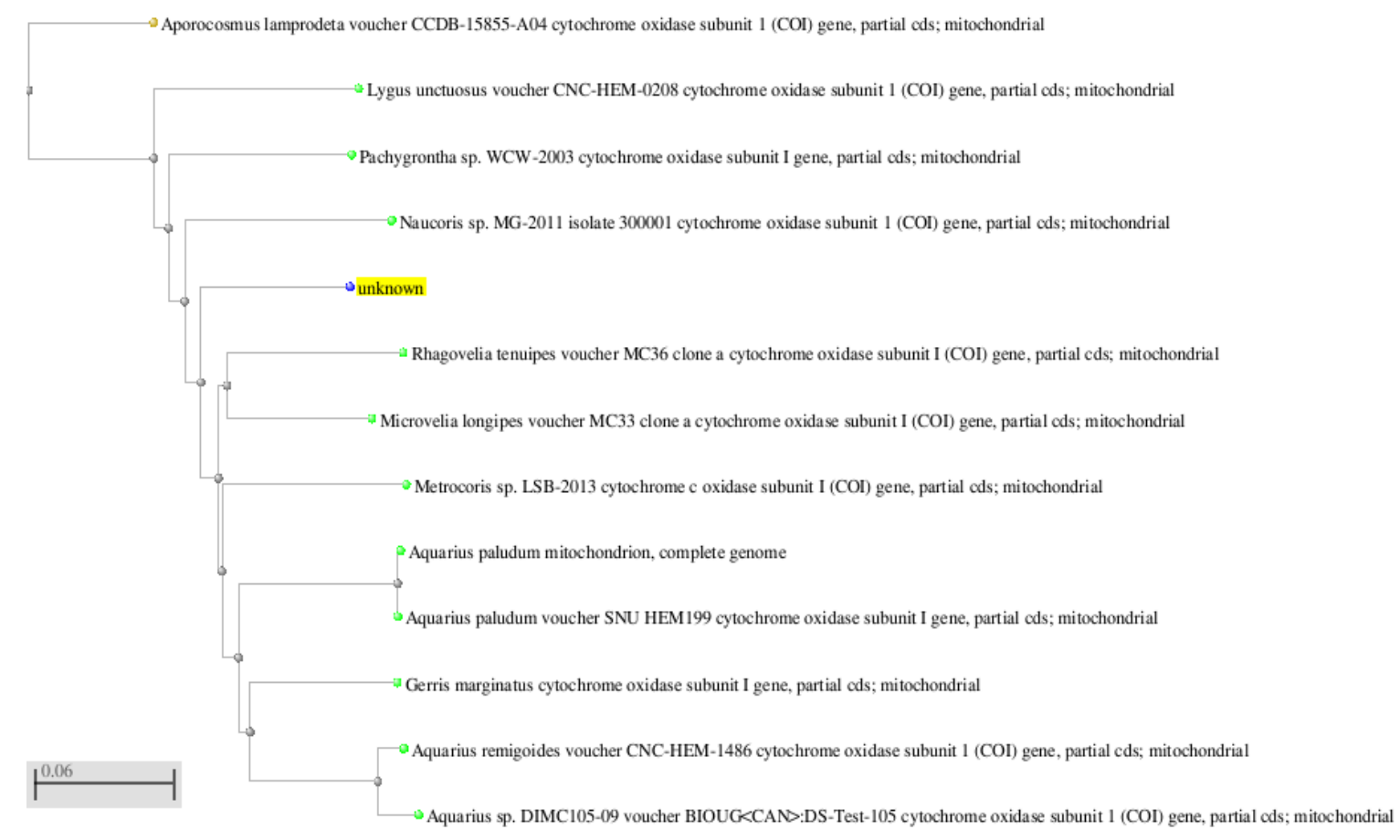

Gambar 5. Pohon filogenetik gen CO1 serangga laut dari perairan Pantai Mokupa dibandingkan dengan data dari NCBI dengan tingkat kemiripan terdekat dan pembanding (outsider). 


\section{KESIMPULAN DAN SARAN}

\section{Kesimpulan}

1. Serangga laut Gerridae yang mendiami daerah pesisir pantai ditemukan pada daerah mangrove yang tenang.

2. Berdasarkan analisis BLAST sekuens gen sitokrom oksidase 1 (CO1) serangga laut yang berasal dari pesisir Pantai Mokupa berbeda dengan sekuens gen sitokrom oksidase 1 (CO1) serangga laut dari family Gerridae yang telah terdata dan terpublikasi di gen bank NCBI.

\section{Saran}

Masih ada banyak serangga laut yang belum teridentifikasi dan belum terdata dalam gene bank NCBI, sehingga penelitian tentang serangga laut yang hidup pada perairan laut Sulawesi Utara perlu dilakukan sehingga bisa didapatkan data yang lengkap terutama untuk melengkapi data biodiversitas biota laut pada daerah perairan laut Sulawesi Utara.

\section{DAFTAR PUSTAKA}

Andersen, N.M. 1998. Marine water strider (Heteroptera, Gerromorpha) of the Indo-Pasific : cladistic biogeography and Cenoizoic palaeogeography. In Biogeography and geological evolution of SE Asia. R. Hall \& J.D. Holdway (eds). Leiden, Netherlands : Backhuys Publisher, pp 341-354.

Andersen, N.M. 2004. The Marine Insect Halobates (Heteroptera, Gerridae). Key for the identification of Halobates Eschschholtz and Related. Csiro
Publishing, Invertebrate Taxonomy, 8 1-15, 861-909.

Andersen, N.M and T.A. Weir. 1994. The Sea Skeater Genus Halobates Eschschholtz (Hemiptera : Gerridae) of Australia : Taxonomy, Phylogeny and Zoogeography. Csiro Publishing , Invertebrate Taxonomy, 8, 861-909.

Andersen, N.M., and L. Cheng. 2004. The marine insect Halobates (Heteroptera: Gerridae) biology, adaptations, distribution, and pylogeny. Oceanography and Marine Biology : An Annual review 2004, 42, 119-180.

Cheng, L. 1966 Studies on the biology of the Gerridae (Hem. Heteroptera) II: The life history of Metrocoris tenuicornis Esaki. Entomol. Mon. Mag. 102, 273-282.

Cheng, L., 1976. Marine Insect. eScolarship University of California. Institution of oceanography. $581 \mathrm{p}$.

Cheng, L., 1985. Biology of Halobates (Heteroptera: Gerridae). Annual Review of Entomology. 30: 111 - 35.

Cheng, L., 1989. Factors Limiting the distribution of Halobates species. EuropeanMarine Biology Symposium. 23:5 - 9.

Folmer, O., M. Black, W. Hoch, R. Lutz and R. Vrijenhoek +, 1994. DNA primers for amplification of mitochondrial cytochrom $c$ oxidase subunit I from diverse metazoan invertebates. Molecular Marine Biology \& Biotechnology. 3(5):294-299. 